\title{
Autorretrato, retrato de familia y autoficción en Días de agosto (2005) de Marc Recha
}

\author{
Self-portrait, Family Portrait and Autofiction in Days of August \\ (2005) of Marc Recha
}

\author{
Gómez Gómez, A. y Parejo, N. 1 \\ Recibido: 8-01-2019 - Aceptado: 12-01-2020 \\ DOI: https://doi.org/10.26441/RC19.1-2020-A7
}

RESUMEN: Este artículo analiza la película Días de agosto de Marc Recha como obra de autoficción. Para ello se toma en consideración la teoría literaria, que es la que ha conformado primero el marco conceptual sobre esta forma del yo, para después observar cómo se manifiestan en el audiovisual. Nos interrogamos sobre las diferencias entre la autobiografía y el autorretrato en sus dimensiones audiovisuales. Especial importancia cobra en este sentido la delegación de la voz narradora en su hermana. Asimismo, se analiza la articulación entre los personajes ficticios y no ficticios, atravesados por la posmemoria en su vínculo con la Guerra Civil española y el paisaje. Finalmente, consideramos que desde el principio se construye un modo de autorretrato audiovisual que se corresponde con el presente mientras el filme se está realizando.

Palabras clave: autoficción; autorretrato audiovisual; poéticas del yo; memoria; posmemoria; paisaje.

\begin{abstract}
This article analyzes the film Days of August by Marc Recha, as an autofiction work. The literary theory is taken into account, shaping the conceptual framework of this form of the self at first, and then observing how it manifests in the audio-visual range. The analysis questions the differences between audio-visual aspects of autobiography and self-portrait. The appointment of the narrator's voice in his sister's part is particularly important in this regard. The article goes on, analyzing the articulation between the fictional and non-fictional characters, traversed by the post-memory in its link with the Spanish Civil War and landscape. Finally, an audio-visual self-portrait is constructed, which corresponds to the present while the film is produced.
\end{abstract}

Keywords: autofiction; audiovisual self-portrait; poetics of self; memory; postmemory; landscape.

\footnotetext{
${ }^{1}$ Agustín Gómez Gómez es Doctor en el programa Evolución cultural y cambio social por la Universidad del País Vasco. Es Profesor Titular de Comunicación Audiovisual en la Facultad de Ciencias de la Comunicación de la Universidad de Málaga donde imparte las asignaturas Teoría de la Comunicación Audiovisual y Lenguaje Audiovisual. Su labor investigadora está centrada en el cine y su relación con otros artes y en el cine rural. aggomez@uma.es, https://orcid.org/0000-0002-1736-0630

Nekane Parejo es Doctora en Ciencias de la Comunicación por la Universidad del País Vasco y Profesora Titular de Comunicación Audiovisual en la Facultad de Ciencias de la Comunicación de la Universidad de Málaga donde imparte las asignaturas de Historia de la Imagen Fija y Método Científico de Investigación en Comunicación. Su labor investigadora está centrada en las relaciones entre el cine y la fotografía y su historia.nekane@uma.es, https://orcid.org/0000-0003-3021-1223
} 


\section{Estado de la cuestión}

Los textos científicos sobre la autoficción en la literatura son abundantes y se han establecido unos perfiles bastante nítidos, pero en el caso del audiovisual queda mucho por hacer. Javier Gómez Tarín y Agustín Rubio señalaron, sobre la problemática del yo en la autoficción cinematográfica, que "la teoría literaria fue asumida en su día por la teoría fílmica con pocas matizaciones y que, en consecuencia, encontraba cada vez más problemas para su aplicación en los análisis de los discursos audiovisuales" (2014, p. 75). Es evidente que la forma en la que se materializa/visualiza al autor, narrador y personaje es diferente en el dispositivo literario que en el cinematográfico. A esto hemos de añadir otra transversalidad más, la del autorretrato como género nacido de la pintura que el audiovisual va a subsumir por ser propio de la imagen. En este sentido, Jean-Luc Godard ya señalaba en $J L G / J L G$ (1993) que no se trataba de una autobiografía audiovisual sino de un autorretrato (Mata, 2015, p. 82; Zumalde, 2011, pp. 147-148), lo que le sirvió para establecer cómo estas dos formas del yo están vinculadas con la temporalidad: el pasado con la autobiografía y el presente con el autorretrato, y cada una de ellas con un problema de puesta en escena. Estas consideraciones han tenido un amplio debate académico que aún se mantiene. Desde Elizabeth W. Bruss, quien negaba la posibilidad de una autobiografía audiovisual a partir de la triangulación del valor de verdad, de acto y de identidad que posee la literatura y que el cine es incapaz de ofrecer (1980); a la desfiguración (ficcionalización) de toda autobiografía de Paul de Man (1984); pasando por Philippe Lejeune que refuta principalmente el valor de verdad de Bruss y se centra en la problemática ficción-documental (2008, pp. 18-22); o Raymond Bellour que parece decantarse por una distinción entre contar o evocar la vida de uno mismo a partir de las retóricas tradicionales de la subjetividad (2009, pp. 287-300).

En nuestro país es posiblemente el libro colectivo Cineastas frente al espejo editado por Gregorio Martín Gutiérrez el que en 2008 puso al alcance de los investigadores en lengua castellana un estado de la cuestión que ha hecho a ese libro ineludible cita bibliográfica. Después han venido otros trabajos que, desde diferentes perspectivas del documental, como desde obras concretas, han ido dibujando un panorama cada vez más esclarecedor. Uno de los investigadores que más ha contribuido en el conocimiento de estas formas audiovisuales ha sido Efrén Cuevas (2008; 2012; 2013), quien ha planteado la problemática a partir del carácter fronterizo de las obras del yo, entre la ficción y la no-ficción, los distintos enfoques autobiográficos o las obras domésticas familiares. A él, además, se debe el primer trabajo sobre el estado de la cuestión en España, lo que ha hecho que en sus trabajos se citen las obras de Albert Solé, Juan Miguel Miralles, Joaquim Jordà, Carla Subirana, Luis Miñarro, Elías León Siminiani, Jorge Rivero, Carlos Ruiz, Fernández de Castro y Miguel Gallardo, Ricardo Iscar, José Luis Guerín, Juan Vicente Córdoba, Mercedes Álvarez, Sandra Ruesga, José Irigoyen, entre otros. Lo importante, en cualquier caso, no es el listado de las obras más relevantes que se han realizado en España en los últimos 20 años, sino el análisis de lo que cada una de ellas focaliza sobre lo autobiográfico, el autorretrato, el diario, el cine doméstico familiar, el reciclaje, lo identitario o lo memorístico, dentro de los formatos ensayísticos o performativos. El último trabajo que recoge todas estas cuestiones es el de Iván Gómez, en "Espejos audiovisuales. Autofiguraciones del yo en el cine contemporáneo" (2017, pp. 13-38), que hace un completo estado de la cuestión y, sobre todo, acerca conceptualmente el tema sobre las diferentes estrategias de puesta en escena que el cine del yo frecuenta.

De cualquier manera, no se ha incidido lo suficiente en las diferencias entre la autobiografía y el autorretrato cuando se trata de obras audiovisuales que parten de la autoficción, porque si en el caso de la autobiografía, el bios se presta a esta formulación, en el caso de la imagen es más esquiva para ficcionarla, porque por muchas máscaras que se ponga siempre será la imagen del autor.

Los estudios antes citados evidencian que los modos autoficcionales audiovisuales del siglo XXI son escurridizos porque toman referencias muy variadas. Las estrategias metadiscursivas referidas 
a las obras del yo, o con temáticas autoidentitarias, se han atomizado tanto que es difícil establecer unas pautas en las que puedan entrar todas las propuestas. De ahí que esta investigación pretenda profundizar en estos conceptos a partir de la película Dies d'agost (2005) y cómo las formas narrativas encuentran acomodo en ella, especialmente las que se mueven entre la autoficción, el autorretrato y dentro de la autobiografía el retrato familiar.

Sin duda Días de agosto es una película de autoficción, heterogénea en sus formas narrativas y en las diferentes estrategias en la puesta en escena. Un filme de ficción que se presenta como real y en el que se insertan modos de no ficción. La estructura ficcional, a modo de road movie, se mezcla con las convenciones del documental de "retrato familiar" y la ficción de la cotidianidad. Marc Recha (Hospitalet de Llobregat, Barcelona, 1970), el autor, deja la narración en una voz over que se presenta como su hermana, mientras que el protagonismo lo comparte durante el viaje con su hermano David.

La obra de Marc Recha ha sido referenciada en varias ocasiones, pero escasamente analizada en profundidad. La revista Nosferatu en 2004 le dedicó un monográfico "Marc Recha al desnudo" en el que además de una entrevista (Vidal, 2004, pp. 7-26) se analizaban brevemente alguna de sus películas hechas hasta ese momento, concretamente El cielo sube (1991) (Angulo, 2004, pp. 32-39), L'àrbe de les cireres (1998) (Casas, 2004, pp. 40-45), Pau i el seu germà (2001) (Batlle, 2004, pp. 46-50) y Les mans buides (2003) (Quintana, 2004, pp. 51-56). Precisamente, la siguiente película que hizo después de ese monográfico fue Días de agosto. Pero más allá de estos textos que muestran algunas de las características de sus filmes, podemos citar solo tres trabajos relevantes. Uno referido a Petit indi de Marina Parés (2015, pp. 111-133) que lo analiza a partir del modelo baziniano de realismo de captación y de reconstrucción, y sobre el dualismo naturaleza-personas. Más próximo a nuestro estudio está el de Pascale Thibaudeau (2009, p. 85-109) que, aunque su análisis se centra en El árbol de las cerezas, Pau y su hermano y Las manos vacías, recoge la idea de paisaje de Recha que está también presente en Días de agosto, esto es, que hay una asociación entre la naturaleza y lo mágico, que huye de la idealización del paisaje, que este está profundamente transformado y que lo humano se deteriora, pero la naturaleza se mantiene. Finalmente es relevante para nosotros el artículo de Ana Paula Sánchez (2007, pp. 1-9) en tanto que se centra en dos cuestiones que nosotros también vamos a ver, la idea del viaje y de la naturaleza en el cine de Recha, ahora sí, incluyendo a Días de agosto. La idea principal, en lo que respecta a nuestra película, es que se trata de un viaje horizontal, el "que transcurre en el trayecto de un lugar a otro en un constante movimiento hasta que se vuelve a casa" [y vertical en el] "que se detiene el viajero para experimentar pausadamente el paisaje y la cultura del sitio" (pp. 3-4).

En nuestro caso, aunque mantenemos la idea de la naturaleza, pero como veremos en su relación con la memoria, nos centraremos en el hecho de que Marc Recha construye un indiscutible relato de autoficción. Si la autobiografía se identifica, entre otras cosas, por la homonimia del autor, narrador y personaje, y la autoficción por la disociación entre alguna de esas partes, en Días de agosto Marc Recha es el autor indiscutible, refuerza la instancia enunciadora como protagonista principal junto a su hermano David y se desprende de la narración que la cede a su hermana. Este es el modelo que Gérard Genette, para la literatura, definió como contradictorio, el del autor diferente al narrador, pero igual al protagonista.

\section{Objetivos y metodología}

Tras lo expresado, los objetivos que nos planteamos son indagar en las formas autorreferenciales a partir de Días de agosto y sus vínculos con la autoficción con el fin de demostrar que la película cuenta con variados modos de autoficción audiovisual que se sitúa indistintamente entre lo que se ha convenido en llamar no ficción y ficción, tanto por la fórmula narrativa escogida como por la historia que cuenta. Después viene explicar la puesta en escena que incide en la construcción de un 
relato familiar; interpretar la voz narradora de la hermana del director; analizar el comportamiento de los personajes secundarios de ficción que actúan a un nivel metaficcional como refuerzo de lo real; puesto que se pone en juego la memoria en presente, pretérito perfecto e indefinido, glosar los modos narrativos que utiliza; y, finalmente, observar el metadiscurso sobre la Guerra Civil española y el paisaje, que actúan como refuerzo de lo narrado.

Para cumplir estos objetivos hemos considerado una metodología cualitativa transdisciplinaria, en el que el objeto de estudio (Días de agosto) entra en contacto con múltiples discursos simbólicamente análogos. Partimos de una codificación de las distintas teorías que sobre las obras del yo se han realizado para considerar en qué dimensión entran en nuestro objeto de análisis. Como la primera línea abierta sobre estos estudios partieron de la teoría literaria, tenemos en cuanta la aplicación, y complejidad, de dichos planteamientos literarios a los audiovisuales.

El neologismo autoficción fue creado desde la literatura por Serge Doubrovsky en 1977 a partir de su libro Fils, donde el autor coincidía con el personaje y lo definía como "ficción de acontecimientos y de hechos estrictamente reales" (Casas, 2012, p. 10; Doubrovsky, 1980, p. 62). Anteriormente, entre 1973 y 1975, Philipe Lejeune dentro de los estudios de las autobiografías, había analizado los diferentes comportamientos de estas formas del yo, y llegó a establecer el famoso pacto autobiográfico (Le pacte autobiographique) en el que autor, narrador y personaje debían coincidir $(\mathrm{A}=\mathrm{N}=\mathrm{P}), \mathrm{y}$ un segundo pacto entre el autor y el lector en torno a la veracidad de lo narrado. El complejo tema narratológico de la asociación o disociación entre narrador y autor, le lleva a Lejeune a establecer la autobiografía en tercera persona cuando el pacto autobiográfico se rompe $\mathrm{A}=\mathrm{P}^{1} \mathrm{~N}$ (Lejeune, 1975, pp. 27-29). Genette exploró las posibilidades de esta relación triangular estableciendo diferentes marcas cuando se disocian algunos de los tres elementos que entran en juego. Así, la ruptura entre narrador y personaje $\left(\mathrm{N}^{1} \mathrm{P}\right)$ define el régimen homodiegético, la del autor y personaje $\left(\mathrm{A}^{1} \mathrm{P}\right)$ heterodiegético y, la que ahora nos interesa, la del autor y narrador en su rigurosa identidad $(A=N)$ definiría el relato factual y su disociación $\left(\mathrm{A}^{1} \mathrm{~N}\right)$ el relato de ficción (Genette, 1993, p. 61). Genette llega más lejos al indicar, siguiendo a Barbara Herrnstein Smith, que la ficcionalización "se define tanto (o más) por la ficcionalización de la narración como por la de la historia” (Genette, 1989, p. 308).

Por aportar todavía otra matización que nos resulta relevante, Manuel Alberca acuñó el concepto de "pacto ambiguo", lo que vendría a ser una forma de entender la autoficción como una oscilación entre el pacto autobiográfico y un pacto ficcional que nos indica que lo narrado pertenece al mundo de lo imaginario. Para que este pacto ambiguo se produzca deben darse

a) unos hechos o elementos claramente autobiográficos, b) otros ficticios, que, mezclados o superpuestos a los primeros, el lector puede reconocer como imposibles de atribuir al autor, y c) una tercera clase de hechos que podrían ser y no ser autobiográficos, y su atribución es prácticamente insoluble para el lector. (Alberca, 2007, p. 182).

Según lo indicado por Genette anteriormente, esto nos lleva a la doble consideración de una ficcionalización por la disociación entre A, P, N y por la propia historia. Efectivamente, en Días de agosto vamos a ver que se produce una ficcionalización de la narración en el momento en el que $\mathrm{N}^{1}$ A y P y, ahora siguiendo a Alberca, de la historia al pasar de forma indistinta de elementos autobiográficos y documentales, a otros ficticios e incluso unos ambiguos o indeterminados. Además, esos tres modos que van saltando de secuencia en secuencia, tienen también su grado. Ana Casas se ha referido a esta idea a partir de los modelos literarios, que ahora trasladamos al audiovisual, cuando señala que la "autoficción alude a un hibridismo que admite todas las gradaciones y, por ello, resulta extremadamente lábil como concepto" (2012, p. 11). Los tres niveles indicados por Alberca, que se corresponden con la autoficción biográfica, la autoficción fantástica y la autobioficción, van a estar presentes en Días de agosto en medida y proporción variables, o si se prefiere el concepto de Casas con diferente gradación. 
Teniendo en cuenta que el objetivo principal es un análisis de contenido de Días de agosto y su ubicación, principalmente, dentro de los conceptos de autobiografía, autorretrato y autoficción audiovisual, debemos examinar cuestiones relativas a la construcción del relato y su estructura. Para el estudio de la obra de Marc Recha tomamos en consideración el análisis fílmico que, según planteamientos de Jaques Aumont y Michel Marie, exploraría el texto fílmico como "una obra artística autónoma, susceptible de engendrar un texto que fundamente sus significaciones sobre estructuras narrativas y sobre bases visuales y sonoras, produciendo así un efecto particular sobre el espectador" (Aumont \& Marie, 1990, p. 18).

A partir de aquí es preciso explicar una serie de categorías en las que nos centraremos para nuestro análisis de Días de agosto: cómo se manifiesta la autoficción en la película, lo que tiene de ficción y de relato veraz, la memoria como argumento, la voz narradora, el tipo de autorretrato(s) y finalmente la importancia del paisaje como constructo de memoria, sin dejar de considerar la transversalidad de estas categorías.

\section{Veracidad y ficcionalización}

La acción se sitúa en un mes de agosto en el que los dos hermanos -David y Marc Recha- realizan un recorrido con una furgoneta alrededor del embalse de Riba-Roja (Tarragona) y por el río Ebro, dándole a la película un aire de road movie. El vínculo con el género del viaje no se reduce al propio movimiento sin un destino claro y con encuentros inesperados, sino que especialmente es un recorrido que transforma a los que lo hacen, en el caso de nuestro protagonista adopta el modo de relato circular puesto que vuelve al punto de partida -el viaje horizontal que señalábamos antes según Ana Paula Sánchez (2007, p. 3)-, reafirmándose en sus planteamientos iniciales, esto es, si el propósito del viaje era alejarse de una inquietud, la de trabajar sobre la biografía de un periodista, el final es el convencimiento de realizar ese trabajo, que es la clausura del relato cuando regresa a su casa. Pero esta road movie también tiene un viaje vertical, al integrarse con el paisaje y, aquí lo excepcional, eludiendo todo vínculo con lo cultural en tanto que los protagonistas que vemos son todos errantes, igual que los Recha, o foráneos, e incluso la experiencia del paisaje lo es sobre una naturaleza transformada. El trayecto, construido con un estilo contemplativo, comienza en Alfarrás (Lleida), pasa por Almatret (Lleida), Cabra del Camp (Tarragona) y termina en Collsuspina (Barcelona). El supuesto viaje aporta el encuentro de personajes imprevistos (una bailarina autostopista, un trompetista guarda forestal y la camarera de un camping) que se mimetizan con los dos hermanos Recha. Estos tres personajes secundarios son ficcionales (los créditos finales lo verifican) y actúan como una extensión de la familia Recha en tres niveles diferentes, como más adelante veremos, pero con puntos de convergencia: espejo de su propia realidad familiar (bailarina), compromiso y memoria (guarda forestal) y relato sobrenatural o extraordinario (camarera).

La película se puede estructurar en cinco partes, que se articulan a partir de la obsesión del director por el fallecido periodista Ramón Barnils, personaje instrumental al que nunca se cita por su apellido, solo por su nombre. Este personaje real -la hermana cuenta que Marc se interesó por ese periodista que murió de cáncer, que fumaba mucho, que estaba casado y tenía tres hijos y que indagaba en cosas que se habían olvidado- es uno de los ejes sobre los que se construye el relato, pues en la película vemos que Marc Recha ha estado documentándose y realizando entrevistas a familiares y conocidos del periodista, incluso el viaje en ese mes de agosto es una forma de desconectar de la obsesión del trabajo, lo que no consigue del todo, y lo que hace que en determinados momentos la película adopte una forma de work in progress que convierte a Marc Recha en el protagonista absoluto de su propia película.

Hemos estructurado a Días de agosto en cinco partes que tienen una continuidad argumental y temática, pero cada una de ellas gira principalmente en una cuestión concreta. 


\subsection{Argumento: entre el viaje y la memoria}

La primera parte es la presentación a partir de una voz over, de la que nos ocuparemos más adelante, de quiénes son los protagonistas -los dos hermanos-. Esto nos remite directamente a uno de los modelos clásicos de las autobiografías, esto es, la familia que sirve como exploración del origen del autor y de su identidad personal. También se muestra el motivo del viaje, tomar distancia de las entrevistas que Marc había hecho a los hijos y amigos de Ramón. Esa parte del relato se visualiza con fotos del periodista Ramón Barnils y su familia. La narradora incide en que Marc sentía "curiosidad por la época de la que hablaba Ramón". De nuevo encontramos elementos propios de las autobiografías, en tanto que incide de manera retrospectiva en un tiempo pasado. Esta referencia es la que vincula a Días de agosto con la profesión del autor, la construcción de una obra audiovisual a partir de la personalidad del periodista fallecido, pero lo que había comenzado como un relato de familia se aleja para hablar de forma indirecta de un tiempo pasado, el de la dictadura franquista, que aunque no es el tiempo del director, que solo vivió los cinco primeros años de su vida bajo el franquismo, es el tiempo histórico de una generación que se ha interrogado sobre la herencia de la dictadura. Esto enlaza con el concepto de posmemoria de Marianne Hirsch (2015): la transmisión de una generación a otra de unos hechos da lugar a una transformación puesto que las nuevas generaciones completan y traducen los acontecimientos próximos, pero no vividos, pues no tienen una relación indexal como la que tienen los que vivieron los hechos. En algunos momentos de la película volverá sobre ese tiempo, incluso en modo de tiempo biográfico a través de su abuelo materno, o en tiempo detenido a través de imágenes que muestran restos de la guerra, o a través de los ruidos de las bombas que reviven el paisaje que transitan los hermanos Recha. La voz over, en cualquier caso, lo expresa sin lugar a dudas: "creía [Marc Recha] que a través de las cosas que había hecho Ramón podría escribir algo sobre aquel periodo".

La segunda parte la marca la aparición de una autostopista errante (Mariona Ordóñez) que quería ser bailarina, que aparece y desaparece sin dejar rastro. Aunque no hay diálogos con este personaje, la narradora nos aporta muchos datos sobre su familia, como que su hermana mayor murió cuando ella era muy pequeña, y en un momento oímos la voz fuera de campo de la joven, mientras la cámara va recorriendo el paisaje de un pueblo abandonado con las casas en ruina, que dice que le hubiese gustado tener hermanos. Su marcha, viene acompañada del robo de una fotografía de Ramón con sus hijos que ella confundió con la familia Recha. Marc realiza una resignificación de las imágenes heredadas al aportar al retrato familiar la idea de construir una identidad. Sin pretenderlo, la autostopista activó de nuevo en Marc la necesidad de "saber más cosas, tal vez volver a escuchar algunas entrevistas, cosas que le habían dicho de cuando las ciudades y pueblos estaban cambiando, cuando todo era una promesa de una nueva prosperidad". Este texto que oímos va acompañado de fotografías en blanco y negro de Francesc Casañas Riera, Ignasi Canals i Tarrats, Pérez de Rozas, Lucia Faraig, Josep Domínguez, Josep María Sagarra, Pau Lluis Torrents, Branguli, Francesc Buxo y otros autores desconocidos, todas entre 1912 y julio de 1936. Estas instantáneas muestran escenas cotidianas de trabajadores, momentos de ocio, cultura, deporte, etc. que remiten a una realidad referencial que el director no ha vivido, pero que nos traslada a una memoria reconstruida sobre una prosperidad que se vio interrumpida con el golpe militar y Guerra Civil de 1936.

La tercera parte comienza cuando aparece Pere (Pere Subirana), un trompetista guarda forestal en excedencia, que vivía en el bosque y recogía los cartuchos de los cazadores. Además de presentar la visión más ecológica, es también la que enlaza de forma directa con la Guerra Civil. Primero es Pere el que cuenta que en un incendio del año anterior explotaban los obuses de la guerra, lo que viene a ser memoria de un pasado vivo. Luego, la narradora desvela que sin saberlo habían llegado hasta Mas Andreu, un caserón que había sido un refugio de la comandancia del $4^{\circ}$ batallón de la 42 división del 
$15^{\circ}$ cuerpo del ejército de la república ${ }^{2}$, donde en 1938 el abuelo materno estaba como miliciano de cultura durante la Batalla del Ebro. Mientras la voz over nos relata las vivencias del abuelo, la cámara va recorriendo el estado ruinoso de la masía y escuchamos como sonido extradiegético ruido de bombas que hacen revivir las penosas condiciones en las que se encontraban durante la guerra.

La siguiente parte es la que corresponde con los relatos más imaginarios y oníricos. En él aparece la camarera de un camping (Fina Susín), un espíritu libre que hacía lo que le gustaba. Este personaje también presenta características errantes. La narradora nos dice que hacía poco que trabajaba en el camping, que de pequeña veraneó en el pueblo con su madre y sus hermanas, que su padre era encofrador y vivían donde encontraba trabajo, hasta que su madre lo dejó. Este fragmento comienza con la búsqueda de un camping para acampar. En el primero que encuentran, aunque parece vacío no hay sitio y en el segundo, el de los alemanes, no se entienden y tampoco resuelven la estancia. De estos últimos nos dicen la narradora que no sabían ni castellano ni catalán y que no les gustaba mezclarse. La narración continúa con el relato fabuloso del pez gato, evocación mítica, como la del monstruo del Lago Ness, aunque en esta ocasión sabemos que su origen es la introducción de un animal por un alemán en 1974 en un entorno diferente al suyo, lo que le sirve para ilustrar el complejo vínculo entre el hombre y la naturaleza. Además, este relato va acompañado de las obras de Land Art que un artista inglés había realizado en un bosque próximo, en el que vivía y del que se alimentaba. Desapareció y muchos creyeron que lo devoró el pez gato y otros que regresó a Inglaterra para buscar a una mujer a la que había amado. También es en este momento cuando Marc tiene un sueño/pesadilla con Ramón Barnils y sus hijos, en el que Carla (sic) tenía una foto de Ramón de los años sesenta con el pelo largo, y Ramón se mostraba molesto por las entrevistas que Marc había hecho sobre él.

La quinta y última parte corresponde a la desaparición de Marc. Comienza con imágenes del embalse y del río Ebro, centrándose en la vegetación de los fondos del agua, de las orillas y de construcciones que quedaron anegadas por el agua. David surca el río en busca de su hermano, pero no le encuentra. La visión del río y sus orillas es de desolación, con el agua que en ocasiones parece estancada con vegetación que forma un manto sobre la superficie. De nuevo aparecen construcciones arquitectónicas en el agua de la presa, en una de ellas con agujeros de bala mientras volvemos a oír un ruido extradiegético de disparos. Finalmente, David regresa a la furgoneta y revisa las cajas con la documentación y videos con grabaciones de Ramón y entiende que es ahí donde debe buscar. Entonces vemos en una puesta en abismo algunos de los fragmentos que rodó, lo que sirve, entre otras cosas, para alejarnos de nuevo de la ficción y aproximarnos a la verosimilitud. Finalmente, en el pueblo donde el periodista vivió los últimos años de vida le encuentra.

La película se cierra con David llevando a Marc a su casa y con la voz de su hermana que vuelve al principio, con la foto inicial de los dos hermanos y la narración que oímos al comienzo de la película sobre cómo ellos hacían cosas juntos y se lo pasaban bien. Añade que David tenía que ir a buscar a su hijo que se lo había dejado a ella para que pudiera acompañar a Marc en el viaje. Y clausura el relato indicando que ahora que el director tenía toda la información que necesitaba, era el momento de encerrarse para escribir sobre Ramón Barnils, aquel hombre que "hablaba de cosas que se habían olvidado o que algunos no querían recordar".

\section{Voz narradora}

Como hemos mencionado, la narración queda en manos de una voz over que se presenta como la hermana de Marc Recha. Se trata de una narradora delegada, extraheterodiégetica según la tipología

\footnotetext{
${ }^{2}$ Los datos se corresponden fehacientemente con el Ejército del Ebro en la zona de Mequinenza. El 15 Cuerpo del Ejército estuvo dirigido por el teniente coronel Manuel Tagüeña y la 42ª División por el mayor Manuel Álvarez Álvarez.
} 
de Genette, que no aparece en la historia, un modelo similar al omnisciente de la literatura. Esa narradora se dirige al espectador una vez que la historia ha terminado y organiza el relato en primera persona, en un yo que aporta algunos datos familiares, como que son cuatro hermanos -Pau, David, Marc y ella, de la que no sabemos su nombre, aunque por otros paratextos sabemos que Mar Batallé es la hermana pequeña (Vidal, 2004, p. 9)- y que la madre se llama Àngels:

cuando nací, el padre de mis hermanos hacía años que vivía en otro lugar. Àngels se separó de él cuando Marc, David y Pau eran muy pequeños. Le veían muy poco, apenas conocían a su familia. A mi entonces me daba rabia, porque ellos tenían un padre y yo no.

También nos dice que mientras sucedían los hechos que cuenta cuidaba del hijo de David. El que ella no haya participado en la historia que cuenta, la convierte en una narradora no testigo y los datos que aporta proceden, lógicamente, del relato que los dos hermanos han hecho de lo, supuestamente, acontecido. Obviamente, la construcción de la narradora es una licencia poética del director que en nada modifica el relato si dicho personaje (empleamos el término personaje en el sentido literal, puesto que aunque sea a través solo del audio no por eso merma su presencia) existe o no. El hecho de que Marc Recha tenga una hermana contribuye a la integración del relato en lo que podría ser una obra de "retrato de familia". Es una narradora heterodiegética en primer grado que cuenta una historia en la que no ha participado, pero al mismo tiempo su implicación como hermana de los protagonistas y del autor, le confiere un doble sentido que afecta al nivel de la enunciación en su marca de fuerte verosimilitud fílmica. En realidad, aunque ella actúa verbalmente como un personaje inscrito en el ámbito de lo familiar, hay muchas dudas sobre la existencia de este personaje in verba más allá del propio relato. La enigmática presentación no nos aclara quién es la hermana, lo que además se complica porque en los créditos finales se indica que la voz pertenece a Berta Reixach. Su función es propiamente narrativa, pero aporta la función emotiva -la función testimonial o de atestación de Genette (1989, pp. 309-310)- no porque haya participado en los hechos que narra, sino porque el vínculo directo por ser la hermana del autor le aporta una posición autorizada que refuerza, por ese lado, una orientación factual.

Ella habla en pasado (las más de las veces) y presente (para focalizar el relato en un momento concreto), lo que le permite expresar sus propios sentimientos y la visión que como parte de la familia tiene sobre los hechos. Lo interesante es que la narradora se convierte en un personaje a mitad de camino entre los reales (Marc, David y el fallecido Ramón) y los ficcionales (autostopista, guarda forestal y camarera del camping). Esta oscilación es la que aproxima el filme al pacto ambiguo de Manuel Alberca antes mencionado: hay datos biográficos y acontecimientos históricos verificables textual y extratextualmente, otros claramente ficticios que se entremezclan con los anteriores y, finalmente, otros que permanecen insolubles.

Si tomamos como referente el famoso pacto autobiográfico de Philippe Lejeune, podríamos decir que este no se produce porque, como ya hemos señalado, la necesaria identidad entre autor, narrador y personaje se rompe en la instancia narradora. En el audiovisual esto no suele ser muy habitual porque la presencia del autor como protagonista, y por lo tanto realizando tareas actorales, aporta al relato el componente de necesario autorretrato $(\mathrm{A}=\mathrm{P})$. Aquí es donde las diferencias entre literatura y audiovisual son más sustanciales porque al pasar al relato de la imagen, nos aproxima el autorretrato audiovisual al pictórico. Esto no quiere decir que desaparezca el literario, sino que simplemente se incorpora un nuevo agente.

La mayor parte de las autoficciones audiovisuales presentan unas hibridaciones que giran en torno al papel del personaje y su identificación con el autor, pero en pocas ocasiones se rompe con el narrador. Dos ejemplos extremos en los que se delega la narración podrían ser Cuadernos de contabilidad de Manolo Miralles (2005), realizada por el sobrino del artista, Juan Miralles Alonso, y en la que participan otros miembros de la familia que son también protagonistas, lo que hace que esta 
película se sitúe, entre otras posiciones, en un modélico retrato familiar. La hija del pintor, Eva, es en la que recae la narración, la que pone voz e imagen, con fuerte presencia en la historia, es decir, una narradora intrahomodiegética. Naturalmente, no estamos ni en una autoficción, ni en una ficción, sino que dicha elección es precisamente para que el componente de veracidad sea lo más fuerte posible. En el otro extremo, más parecido al caso de Días de agosto, encontramos Nenyure (Jorge Rivero, 2004), donde la narración queda en una voz, también femenina, en primera persona que, como ha señalado Efren Cuevas, se convierte en un "filtro distanciador que desorienta al espectador al desvincular a la narradora de la firma del autor, negando así una primera lectura autobiográfica" (2013, p. 7). Efectivamente en Nenyure, no sabemos quién es esa narradora sin identidad que habla en primera persona, y que el propio director la ha señalado como no protagonista (Rivero, 2010, p. 327), lo que la convierte en una voz expositiva que emplea la primera persona como licencia poética. De nuevo vemos que existe una ruptura del narrador y autor, aunque eso no merma el carácter autobiográfico del relato, que por lo demás se refiere a la memoria de Jorge Rivero sobre el paisaje de la Cuenca Minera asturiana de su infancia y juventud.

\section{Yo, Marc Recha: autorretrato audiovisual}

La presencia del autor en forma de protagonista coincidente homónimamente aporta, necesariamente, un autorretrato. Hay una primera distinción que es necesario establecer en el autorretrato audiovisual, la de que la instancia autor y protagonista se identifiquen. Si en Ocho y medio (Otto e mezzo, 1963) nunca diríamos que hay un autorretrato de Fellini, porque, aunque la película hable de él, lo hace a través de un alter ego llamado Guido Anselmi interpretado por Marcello Mastroianni. Tampoco podemos establecer que en las películas de Woody Allen exista un autorretrato, porque, aunque sea autor y protagonista, éste nunca se presenta como Woody Allen. Algo diferente es el tratamiento de la autoficción en las obras ficcionales. Luz Herrera Zamudio, establece tres opciones: "un autor que interpreta a un personaje con el cual comparte el nombre o un derivado; o un autor que comparte el nombre o un derivado con un personaje interpretado por otro actor; o un autor que interpreta a un personaje de nombre diferente o anónimo" (2007, p. 54). Lógicamente, para el autorretrato solo nos vale la primera de las opciones. Añade, además, que hay una forma directa de homonimia entre autor y personaje -la Completa (el nombre del autor coincide con el personaje) y por Transformación (el nombre aparece oculto, pero se puede descubrir sin indicaciones del texto, paratexto u otras obras)- y otra indirecta -por Sustitución (se utiliza un nombre que no es el del autor, pero guarda una relación con el del autor) y Cifrada (el protagonista tiene coincidencias con el autor)-(2007, pp. 54-59). Obviamente, si volvemos al autorretrato audiovisual y nos separamos de la autoficción por un momento, veremos que de estos modelos únicamente nos sirven para el autorretrato los dos indirectos, al menos siempre que consideremos al autorretrato como "un espejo que refleja el rostro de su autor y, a través de él, su espíritu" (Calvo, 2005, p. 193). Esta definición de Marsilio Ficino en su Theologia Platonica de immortalitate animorum (1474), ha sido la que ha alentado y enriquecido el concepto desde el Renacimiento hasta la actualidad. Si el término se construye con el autos -el sí mismo- más el retrato -representación de una persona real, según lo define por ejemplo María Moliner-, obtendremos la simple definición de que un autorretrato es la imagen de sí mismo.

Lo indicado anteriormente nos lleva a la consideración de la construcción de un autorretrato de Marc Recha en Días de agosto de forma ortodoxa. Él es autor y es protagonista cuyo nombre coincide con el suyo y con su profesión, la de director de cine. De esta manera, esta instancia autorreferencial se cumple completamente. Para incidir todavía más en ello, incluye también un autorretrato familiar, pues se muestra junto a su hermano David y se incorpora información sobre sus otros dos hermanos, y se cita a su madre y padre. Sin embargo, el equilibrio que produce entre la autoficción y el autorretrato, hace que el recorrido sea algo más heterodoxo. 
José Luis Brea en "Fábricas de identidad. Retóricas del autorretrato" parte de un hecho diferencial entre autobiografía y autorretrato. En la primera coinciden el yo de la enunciación y el del enunciado de manera que tiene como resultado un efecto de verdad añadido sobre ese yo externo al discurso y productor del texto. Por el contrario, en el autorretrato lo que aparece en la obra no es un presunto "sujeto pre-existente", sino un "sujeto-en-obra" (2008, p. 149). Efectivamente, al autorretrato parece importarle menos el he sido o he hecho que el saber quién soy. Puede ocurrir que existan referencias al pasado, a experiencias vividas, pero estas se encuentran, por lo general, subsumidas por la autorreflexión y la búsqueda de la identidad en el momento coetáneo al de la ejecución de la obra. Dentro de las diferencias que se han resaltado entre la autobiografía audiovisual, e incluimos ahora aquí también a la autoficción, y el autorretrato es que en los primeros hay una preponderancia de la continuidad narrativa y de valores cronológicos que se identifican con la vida del sujeto narrado (Bellour, 2009, pp. 293-300), mientras que en el autorretrato la exposición del yo se caracteriza por la discontinuidad y por la adopción de modelos narrativos fragmentarios, polifónicos y, muchas veces, aparentemente incoherentes (Schefer, 2008, p. 116).

Esta definición se ajusta a lo que Godard plantea en su peculiar autorretrato en $J L G / J L G$, que recordemos tiene como subtítulo, Autorretrato de diciembre, pues compone una mixtura compleja mientras trabaja, reflexiona y lee, en ocasiones trascendiendo a otros momentos y recuerdos del pasado, lo que tiene como resultado un relato formado por un conjunto de citas literarias, históricas, artísticas, filosóficas y cinematográficas - principalmente- que parecen inconexas, para configurarse como ser cultural. Esto, que se circunscribe perfectamente a un ensayo audiovisual, sin dejar de ser un autorretrato, se aleja de Días de agosto en el sentido de que Recha adopta un modo narrativo lineal que podríamos enunciarlo como Autorretrato de agosto en el que la sucesión de los hechos se mueve en una relación de causa y efecto, perfectamente coherentes y conexos.

\section{Paisaje y memoria}

Marc Recha ha definido la película como "libertaria, no sólo por la simbología ácrata que desprende y en la que nos educaron, sino por mostrar la confluencia de la naturaleza en todos los elementos que muestra" (Recha, 2006, párr. 3). Efectivamente, el paisaje es otro de los grandes protagonistas en su dimensión de sedimentación del pasado. Eduardo Martínez de Pisón se ha referido al paisaje como "un proceso acumulador histórico sobre el potencial ecológico, de manera que fijan, funcionalmente, el legado del pasado" (2009, p. 37). La idea del legado histórico en Días de agosto se pone de manifiesto en tanto que el espacio se corporiza en su dimensión natural, histórica, cultural, social y se aferra a una concreta localización de los paisajes que recorre. Si como señala Carmen Pena, a partir de Alexander Pope, cada paisaje posee un poderoso sentido del tiempo porque es la historia de ese espacio (Pena, 2010, p. 508), Recha no elude en ningún momento ese tiempo, aunque pueda estar trufado de referentes reales o puntos de vista imaginarios.

Marc Recha utiliza diferentes recursos formales para la construcción del paisaje. Alterna la cámara fija con grandes planos generales y trávelin desde coches, trenes y barcas que recogen el paisaje. Pero lo relevante es que entre las opciones de construir un paisaje narrativo o contemplativo -según tipología de Martin Lefebvre (2011, pp. 61-78)- escoge la contemplativa con el consiguiente aislamiento de lo observado. El viaje que realizan en una furgoneta roja por la Cuenca del Ebro, en un verano de sequía, lleno de silencios, aporta a la naturaleza una dimensión especial. No se trata de un paisaje amable. Existe un deliberado contraste entre la sequía, con imágenes de la tierra seca, cuarteada y pequeños insectos inmóviles, y el agua del pantano, grandes extensiones de naturaleza junto a fábricas, una central nuclear, ruinas de casas y pueblos abandonados, antenas de televisión entre olivos, tuberías que atraviesan montes y carreteras, canales de agua, esclusas..., disparidad 
visual que aumenta con los planos, a menudo contemplativos, de estructuras arquitectónica y de ingeniería que aportan una dimensión de intervención cultural en el paisaje.

La idea del paisaje intervenido es permanente durante todo el metraje. En ocasiones serán unas ovejas que se apropian del espacio ocupado por los Recha, o el propio embalse que invadió pueblos, como el campanario de una iglesia que emerge del agua con el reloj parado a las 2:25, o la conducción del agua a través de enormes tuberías, o las carreteras, o los pueblos y casas abandonadas, o el relato de los peces exógenos introducidos en los pantanos, o el arte de pintar árboles y rocas en la naturaleza, o las esclusas del Ebro..., en definitiva, un sinfín de referencias que aluden a esa transformación. Ese paisaje intervenido no es celebratorio, es visto más como una anomalía que como una modificación natural. Eso nos remite a un tiempo anterior en el que las cosas eran diferentes, y ahí entra de nuevo Ramón Barnils, y en definitiva la memoria, que no es más que el recuerdo de otro tiempo. Porque Marc Recha no hace una alabanza de aldea al modo de Antonio de Guevara o elogio de que cualquier tiempo pasado fue mejor a la manera de Jorge Manrique, sino que simplemente se resiste al olvido. Podemos decir que su planteamiento se acerca a lo que Pierre Nora ha definido como lugares de memoria, "una historia que no es ni resurrección, ni reconstitución, ni reconstrucción, ni incluso representación, sino rememoración [...] Una historia que no se interesa por la memoria como recuerdo, sino como economía general del pasado en el presente" (Nora, 1998, pp. 25-26).

Con ese presupuesto, Marc Recha va incorporando, a partir del anclaje autobiográfico, un relato sobre el paso del tiempo y sus estragos, con especial detenimiento en la Guerra Civil. Es en ese momento en el que la Batalla del Ebro se hace más presente. Primero lo vemos en las huellas de las balas en estructuras arquitectónicas que han quedado dentro de las aguas del pantano, luego cuando se encuentran con el trompetista guarda forestal -la visión más ecológica de relato- que les cuenta que con los incendios del año anterior explotaban los obuses de la guerra, y finalmente cuando llegan a Mas Andreu, un caserón que había sido un refugio de su abuelo materno como soldado del ejército republicano durante la Batalla del Ebro. Mientras la voz over de la hermana nos relata las vivencias del abuelo, escuchamos como sonido extradiegético el ruido de las bombas. Aunque a menudo relacionamos el paisaje como una imagen, posiblemente porque su origen está en la pintura, también lo es literario ${ }^{3}, \mathrm{y}$ en el caso del audiovisual es la combinación de imagen y sonido. Para Michael Jakob "un paisaje no es un territorio, ni un país, ni un lugar, sino una representación icónica y verbal" (Jakob, 2013, p. 29). Sin dejar de estar completamente de acuerdo en la definición de Jakob, nos interesa destacar ahora el valor del audio porque Marc Recha construye un paisaje en el que la combinación de imagen y sonido están desincronizadas en el tiempo. La primera corresponde al presente y la segunda al pasado, una a los bosques y espacios que se abren desde el Ebro hacia el norte, la otra a los sonidos de la Batalla del Ebro, que se unen en la construcción de un paisaje de memoria.

\section{Conclusiones}

Gérard Genette a la hora de definir la autoficción señalaba "yo, autor, voy a contaros una historia cuyo protagonista soy yo, pero nunca me ha sucedido" (1993, p. 70). March Recha podría apropiársela, pero modificándola en parte: yo, autor, voy a contaros una historia cuyo protagonista soy yo, y mi hermano, la contará mi hermana, pero nunca nos ha sucedido.

Días de agosto es una obra de autoficción, en el que se insertan retazos autobiográficos, en su mayor parte vinculados con la familia y narrado por la hermana, con abundantes momentos de au-

\footnotetext{
${ }^{3}$ Aunque no es el espacio para tratar el tema del paisaje en la literatura, pongamos como ejemplo el conocido viaje de Petrarca al Mont Ventoux que narró en Familiarum rerum libri de 1336.
} 
torretratos audiovisuales que nos muestran el presente del director. Recha juega con la ficción y la apariencia de la veracidad en un proceso en el que las causas y efectos están claras. Hay imágenes que parecen irreales, como el campanario de una iglesia que emerge de las aguas del pantano, pero que son la realidad de una intervención humana en lo que fue una forma cultural. Ahí es donde la memoria se hace fuerte en su película. La toma a partir del relato de Ramón Barnils y lo lleva a la memoria de la Guerra Civil. Incluso el sonido de las bombas del pasado en las imágenes del presente son el salto permanente entre la apariencia de veracidad desde la ficción y la ficción que se aproxima a la realidad.

Cuando se ha abordado el estudio del yo audiovisual se ha hecho principalmente desde la autobiografía, pero quizá no esté de más recordar que en toda autobiografía hay un conjunto de autorretratos, pero en un autorretrato no hay necesariamente una autobiografía. Y aquí es donde encontramos el equilibrio de Marc Recha para moverse entre la autobiografía y la autoficción dentro de un autorretrato. La capacidad discursiva de su autorretrato audiovisual da lugar a que se coloque en un lugar privilegiado para expresar a través de su propia corporeidad la búsqueda de sí mismo, interrogarse sobre quién soy (autorretrato) e incorporar a la familia en una doble vertiente de autorretrato y autobiografía, y esta última a su vez con otra derivada que le lleva a un pasado que es rememorado a través de fotografías de antes de la Guerra Civil, de esta a través de su abuelo materno y del sonido de las bombas y la imagen de los proyectiles en la piedra y de otro pasado más reciente a través de Ramón Barnils, lo que es el espacio de una memoria que responde a un hemos sido colectivo.

Marc Recha convoca en Días de agosto el presente y el pasado, que se corresponden con una fuerte presencia del autorretrato personal y familiar (lo que está ocurriendo) y una débil autobiografía (proceso de memoria), pero para que la memoria no pierda su eficacia, esta toma unos derroteros diferentes al autos, y lo lleva por diferentes caminos de la mano del relato de Ramón Barnils, de la historia reciente y del paisaje. Al analizar las formas autorreferenciales en Días de agosto, hemos podido establecer el comportamiento de ese equilibrio entre autorretrato y autobiografía. El primero se manifiesta especialmente con el propósito de ser observado como 'sujeto en obra' que realiza su propia película en una clásica fórmula de work in progress o "sujeto-en-obra". La autobiografía es el proceso retrospectivo, pero esta no se reduce a contar la vida personal o familiar, sino la colectiva, o si se prefiere la de la historia reciente de España. Para ello invoca a su abuelo, pero sobre todo al territorio y el paisaje, lo que de nuevo es una oscilación entre el yo individual y el yo colectivo.

En Días de agosto confluyen marcas autorreferenciales como la autobiografía, el retrato familiar, la autoficción o la metaficción, transparencia en el proceso creativo, fluctuación entre realidad y ficción y entre el pasado y el presente, porque como bien indica Laia Quílez a propósito de la posmemoria "la imagen del pasado no puede ser una huella separada del presente y [...] el presente se resignifica continuamente a partir de una evocación siempre problemática del pasado" (Quilez, 2014, p. 69).

La elección formal elegida es la autoficción a partir de una película de ficción. Esta opción que se observa tanto en la trama como en lo formal, se hace fuerte en la elección de la voz narradora. Al delegarla en su hermana, se rompe el pacto autobiográfico de Lejeune y la ruptura entre el autor y narrador, siguiendo a Genette, nos lleva a un relato de ficción. Matizando más, y ahora según Manuel Alberca, nos aproximamos al pacto ambiguo, entre unos hechos claramente autobiográficos, otros ficticios y finalmente otros de imposible atribución. La poca frecuencia en el audiovisual en el que el autor es protagonista, pero cede la narración, y en este caso a un miembro de la familia, la convierte, además, en protagonista por exclusión.

Los tres personajes secundarios de ficción actúan a un nivel metaficcional como refuerzo de lo real. El primero de ellos, la bailarina autostopista, es la que vincula el relato a la importancia de la familia, una familia por lo demás poco convencional. El segundo, Pere, el guarda forestal en excedencia 
es el nexo con lo real y el principal enlace con la memoria, además de representar el compromiso ecológico. Finalmente, la camarera es la apertura, a partir de lo real, con el relato imaginario (pez gato, ingles que pintaba el bosque o el sueño de Marc con Ramón y sus hijos).

A lo largo de todo el metraje el proceso de referencia a la memoria se hace con una doble temporalidad, la imagen en presente, normalmente a partir de ruinas o intervenciones 'anómalas' en la naturaleza (en ambos casos la imagen en su condición de índex, como huella de lo que fueron), y la banda sonora en pasado, en varias ocasiones incorporando a las imágenes del presenta el ruido referencial de pasado.

\section{Bibliografía}

Alberca, M. (1996). El pacto ambiguo. Boletín de la Unidad de Estudios Biográficos, 1, 9-18. http://revistes.ub.edu/index.php/bueb/article/view/27946/28770

Alberca, M. (2007). El pacto ambiguo. De la novela autobiográfica a la autoficción. Biblioteca Nueva.

Angulo, J. (2004). El cielo sube. Nosferatu. Revista de cine, 46, 32-39.

Aumont, J. y Marie, M. (1990). Análisis del film. Paidós.

Batlle Caminal, J. (2004). Pau i el seu germà. Nosferatu. Revista de cine, 46, 46-50.

Bellour, R. (2009). Entre imágenes. Foto, cine, video. Ediciones Colihue (París, 2002).

Brea, J. L. (2008). Fábricas de identidad (retóricas del autorretrato). En El tercer umbral. Estatuto de las prácticas artísticas en la era del capitalismo global (pp. 143-155). Cendeac, Ad hoc.

Calvo Serraller, F. (2005). Los géneros de la pintura. Tauros.

Casas, A. (2012). El simulacro del yo: la autoficción en la narrativa actual. En A. Casas (ed.). La autoficción, Reflexiones teóricas (pp. 9-42). Arco/Libros.

Casas, Q. (2004). L'arbre de les cireresel peso y el paso del tiempo. Nosferatu. Revista de cine, $46,40-45$.

Cuevas Álvarez, E. (2008). Del cine doméstico al autobiográfico. Caminos de ida y vuelta. En G. Martín Gutiérrez (ed.). Cineastas frente al espejo (pp. 101-120). T\&B.

Cuevas Álvarez, E. (2012). El cine autobiográfico en España. Una panorámica. Rilce: Revista de filología hispánica, 28, 1, 106-125. https://www.unav.edu/publicaciones/revistas/index.php/rilce/ article/view/2990

Cuevas Álvarez, E. (2013). Fronteras del yo en el documental español contemporáneo. En Norberto Mínguez (ed.), Ficción y no ficción en los discursos creativos de la cultura española (pp. 115-128). Iberoamericana - Vervuert.

De Man, P. (1984). La autobiografía como desfiguración [1979]. En La retórica del romanticismo (pp. 147-158). Akal.

Doubrovsky, S. (1980). Autobiographie/vérité/psychanalyse. Citado por la edición española (2012). Autobiografia/verdad/psicoanálisis. En A. Casas (ed.). La autoficción, Reflexiones teóricas (pp. 45-64). Arco/Libros.

Genette, G. (1989). Figuras III. Editorial Lumen. 
Genette, G. (1993). Ficción y dicción. Editorial Lumen.

Gómez, I. (2017). Espejos audiovisuales. Autofiguraciones del yo en el cine contemporáneo. En Ana Casas (Ed.), El autor a escena. Intermedialidad y autoficción (pp. 13-38). IberoamericanaVervuert.

Gómez Tarín, F. J. y Rubio Alcover, A. (2014). Narrador fílmico y autoficción. Nuevas posibilidades del punto de vista. En C. Rodríguez Fuentes (ed.), Reflexiones y análisis sobre textos audiovisuales (pp. 75-100). La Laguna: Cuadernos artesanos de Comunicación.

Herrera Zamudio, L. E. (2007). La autoficción en cine. Una propuesta de definición basada en el modelo analítico de Vincent Colonna. Universidad Complutense de Madrid.

Hirsch M. (2015). La generación de la posmemoria. Escritura y cultura visual después del Holocausto. Carpe Noctem.

Jakob, M. (2013). Le paysage. Infolio.

Lefebvre, M. (2011). On Landscape in narrative cinema. Canadian Journal of Film Studies. Revue canadienne d'études cinématographiques, 20, 1, 61-78.

Lejeune, P. (1975). Le pacte autobiographique. Seuil.

Lejeune, P. (2008). Cine y autobiografía, problemas de vocabulario [1998]. En G. Martín Gutiérrez (ed.). Cineastas frente al espejo (pp. 13-33). T\&B.

Martín Gutiérrez, G. (ed.). (2008). Cineastas frente al espejo. T\&B.

Martínez de Pisón, E. (2009). Miradas sobre el paisaje. Biblioteca nueva.

Mata, M. M. (2015). $J L G / J L G$ autorretrato de diciembre: el invierno en que Godard se puso de luto. Fotocinema. Revista cientifica de cine y fotografia, 11, 81-111. http://dx.doi.org/10.24310/ Fotocinema.2015.v0i11.6076

Nora, P. (1998). La aventura de Les lieux de mémoire. En J. Cuesta Bustillo (ed.), Memoria e historia, Revista Ayer, 32, 17-34.

Parés Pulido, M. (2015). La inscripción del cuerpo en un espacio-tiempo en transformación en Petit indi. En A. Gómez \& A. Melendo (eds.) Paisajes visuales (pp. 111-133). Cuadernos Artesanos de Comunicación.

Pena López, C. (2010). Paisajismo e identidad. Arte español. Estudios Geográficos Vol. LXXI, 269, 505-543. https://doi.org/10.3989/estgeogr.201017

Quílez Esteve, L. (2014). Hacia una teoría de la posmemoria. Reflexiones en torno a las representaciones de la memoria generacional. Historiografias, 8, 57-75. https://doi.org/10.26754/ ojs_historiografias/hrht.201482417

Quintana Morraja, Á. (2004). Fronteras y residuos de un presente esquizofrénico. Les mans buides de Marc Recha. Nosferatu. Revista de cine, 46, 51-56.

Recha, M. (21/06/2006). El hermano de Marc Recha. Diario Vasco. https://www.diariovasco.com/ pg060721/prensa/noticias/Cultura/200607/21/DVA-CUL-244.html

Rivero, J. (2010). La identidad social en el paisaje urbano: edificando Nenyure. C. Cornejo, J. Morán y J. Prada (coords.). Ciudad, territorio y paisaje. Reflexiones para un debate multidisciplinar (pp. 327-331). CSIC. https://dialnet.unirioja.es/servlet/articulo?codigo=3263145 
Sánchez Cardona, A.P. (2007). Viaje y territorio. Percepción y apropiación de la naturaleza en el cine de Marc Recha. OCEC (Observatori del Cinema Europeu Contemporani) Universitat Pompeu Fabra, 1-9. http://www.ocec.eu/pdf/2007/sanchez_anapaula.pdf

Schefer, R. (2008). Vi-deo memoria. Autobiografías, autorreferencialidad y autorretratos. En J. La Ferla (coord.), Historia crítica del video argentino (pp. 115-125). Fundación Eduardo Constantini y Fundación Telefónica.

Thibaudeau, P. (2009). Cine, realidad y realismo(s). El mundo rural en las películas de Marc Recha. En P. Poyato (ed.) El realismo y sus formas en el cine rural español (pp. 85-109). Córodba: Diputación de Córdoba.

Vidal, N. (2004). Entrevista a Marc Recha. Nosferatu. Revista de cine, 46, 7-26.

Zumalde, I. (2011). Godard a través del espejo. JLG/JLG Autoportrait de décebre (1993). En R. Esparza \& N. Parejo (Coords.), Solos ante la cámara: biopics de fotógrafos y cineastas. (pp. 147156). Luces de Gálibo. 